\title{
MEMBENTUK GENERASI YANG TAKUT AKAN TUHAN
}

(Dr. Irfan F. Simanjuntak, M.Th)

\begin{abstract}
Abstraksi: Tulisan ini bertujuan untuk menyajikan cara-cara yang bisa ditempuh keluarga agar terbentuk generasi yang takut akan Tuhan. Dalam tulisan ini diuraikan bahwa takut akan Tuhan adalah kehidupan yang menyadari penuh akan eksistensi Tuhan, percaya pada-Nya dan karena itu taat. Kehidupan seperti ini perlu ditanamkan pada generasi muda (anak-anak dan remaja) mengingat semakin derasnya arus pencobaan yang menghadang dan ingin menjatuhkan kehidupan anak-anak Tuhan. Untuk mencapai hal yang demikian, tulisan ini menyarankan tiga hal mendasar yang perlu dilakukan orangtua. Pertama, menyediakan lingkungan yang positif. Kedua, menjadi teladan. Dan ketiga, memberi kasih sekaligus disiplin. Dengan melaksanakan ketiga hal ini diharapkan orangtua berhasil membentuk generasi yang takut akan Tuhan.
\end{abstract}

Kata-kata Kunci: Orangtua, generasi, teladan, lingkungan, kasih

\section{PENDAHULUAN}

Anak adalah generasi penerus, baik bagi orangtua, gereja, masyarakat, maupun negara. Itu artinya, berhasil tidaknya mendidik anak menjadi penentu cerah atau muramnya masa depan keempat dimensi kehidupan di atas. Dengan demikian mendidik anak agar menjadi generasi yang mumpuni adalah dambaan setiap orang. 
Dalam komunitas Kristen, tujuan utama mendidik anak tentu saja bukan hanya agar menjadi pintar. Tanpa mengecilkan makna kepintaran, anak-anak Kristen harus dibentuk agar menjadi generasi yang takut akan Tuhan. Terlalu banyak orangtua yang mengabaikan tujuan luhur ini, sehingga banyak sekali didapati anak-anak yang bukan cuma bersikap nakal, tapi punya sikap dan kencederungan yang mencemaskan. Jika tidak ada tindakan preventif, hal ini tentunya akan membawa pengaruh buruk yang akhirnya menyebabkan kerusakan bahkan kehancuran. Itulah sebabnya, membentuk generasi yang takut akan Tuhan harus diupayakan. Dan itulah tujuan dari makalah ini, untuk menyelidiki bagaimana membentuk generasi yang takut akan Tuhan.

\section{PEMBENTUKAN GENERASI YANG TAKUT AKAN TUHAN}

\section{Generasi yang Takut akan Tuhan}

Takut akan Tuhan adalah kondisi dimana kehidupan seseorang benar-benar percaya dan karena itu menaati Tuhan. Alkitab, baik Perjanjian Lama maupun Perjanjian Baru menjadikan hal ini sebagai salah satu ciri kehidupan umat Allah. Dengan demikian, orang yang mengaku percaya, dari generasi ke generasi harus memiliki ciri ini.

Sikap takut akan Tuhan merupakan "ketakutan yang kudus, dimana sikap ini adalah berdampak dari pengenalan orang 
percaya akan Allah yang hidup."1 Ini berarti pengenalan yang benar akan Tuhan adalah dasarnya dan takut akan Tuhan adalah hasilnya. Dan sikap takut tersebut terwujud dalam ketaatan kepada Allah. Longman berkata bahwa takut akan Tuhan, tidak dapat dihindari, memimpin kepada ketaatan karena ketakutan yang dihasilkan tidak membuat kita lari dari Allah melainkan memberi perhatian dan mendengarkan-Nya. ${ }^{2}$ Oleh karena itu, dalam konteks tulisan ini, penulis meyakini bahwa hidup yang takut akan Tuhan dimulai ketika seorang anak menyadari keberadaan dan kekuasaan Allah dan karena itu secara konsisten percaya dan taat kepada-Nya.

Untuk memiliki kehidupan yang demikian, secara khusus bagi generasi muda masa kini, keluarga khususnya orang tua memiliki peran yang signifikan. Pembentukan yang dilakukan secara terukur dan terencana oleh orang tua merupakan unsur yang tidak dapat diabaikan. Sebagaimana yang diungkapkan oleh Tripp, "Anak-anak harus dibawa agar mengerti bahwa hidup sebagai ciptaan dalam dunia milik Allah berarti tunduk kepada Allah yang baik dan bijaksana dalam segala hal."3 Oleh karena itu orang tua perlu memikirkan, merencanakan dan melaksanakan cara-cara yang dapat membentuk anak-anak mereka menjadi takut akan Tuhan.

\section{Membentuk Generasi yang Takut akan Tuhan}

\footnotetext{
1J.D. Douglas, "Takut," dalam Ensiklopedi Alkitab Masa Kini, jil. II (Jakarta: YKBK/OMF, 1995), 438-439.

${ }^{2}$ Tremper Longman III, The Fear of The Lord is Wisdom (Grand Rapids, MI: Baker Academic, 2017), 11.

${ }^{3}$ Tedd Tripp, Menggembalakan Anak Anda (Malang: Gandum Mas, 2002), 208.
} 
Karena terbatasnya ketersediaan ruang dalam makalah ini, maka bagian ini akan mengusulkan tiga hal yang penulis anggap baik dan mendasar dalam membentuk generasi yang takut akan Tuhan.

\section{Menyediakan Lingkungan yang Positif}

Salah satu faktor yang efektif membentuk generasi yang takut akan Tuhan adalah kesiapan orangtua untuk menyediakan lingkungan rumah yang positif bagi pertumbuhan iman anak sedari awal. Sudah merupakan sebuah konsensus bahwa rumah (baca: keluarga) adalah tempat pertama dan utama untuk membentuk iman anak. Beriman atau tidaknya (atau takut akan Tuhan atau tidak) anak-anak sangat dipengaruhi oleh kondisi dan pembentukan di dalam keluarga. Alasan yang baik terhadap hal ini diberikan oleh Thompson dengan mengatakan: "Karena keluarga asal adalah konteks utama kehidupan dan hubungan sehari-hari selama masa-masa pembentukan, tampaknya cukup beralasan untuk menyimpulkan bahwa keluarga asal adalah tempat pertama pembentukan rohani."4 Dengan nuansa yang hampir sama Dinkmeyer dan McKay mengatakan, "Keluarga menyediakan lingkungan dan setting yang mengekspos anak kepada serangkaian asumsi tentang kehidupan. Sifat, kepercayaan dan nilai yang biasa dipegang muncul dari atmosfir ini." ${ }^{5}$ Dengan demikian setiap keluarga Kristen perlu menyadari

${ }^{4}$ Marjorie L. Thompson, Keluarga Sebagai Pusat Pembentukan (Jakarta: BPK Gunung Mulia, 2012), 10.

${ }^{5}$ Don Dinkmeyer dan Gary D. McKay, Raising a Responsible Child (New York: Fireside, 1996), 33. 
pentingnya ketersediaan lingkungan yang positif bagi pertumbuhan iman anak.

Lingkungan rumah yang positif bisa dilakukan dengan banyak cara. Salah satu yang bisa ditawarkan adalah dengan menjadikan keluarga atau rumah sebagai "gereja" kecil dimana anak dikembangkan kepekaannya akan eksistensi Tuhan. Atau meminjam pemikiran Dolores Leckey, sebagai "tempat bernaung yang kudus."6 Hal ini bisa dicapai, contohnya dengan ibadah keluarga. Ibadah keluarga adalah sarana yang tidak bisa diabaikan dalam membentuk keimanan anak-anak. Namun bukan saja menumbuhkan iman, ibadah keluarga juga menghasilkan keharmonisan. Menurut penelitian Pitirin Sorokin, dekan Fakultas Sosiologi Universitas Haver, ibadah keluarga sangat berhubungan erat dengan keharmonisan keluarga, sebab keluarga yang setiap hari mengadakan ibadah keluarga, persentasi perceraian terjadi hanya 15 per $1000 .{ }^{7}$ Keluarga yang harmonis, lengkap, terbuka dan beriman tentunya menjadi lingkungan yang ideal bagi terbentuknya keimanan anak-anak anggota keluarga.

Hal lain yang bisa dilakukan adalah menjadikan keluarga sebagai tempat saling membangun. Untuk mewujudkan hal ini, orangtua tentunya perlu mengupayakan suatu kepemimpinan yang bersifat demokratis dan bukan otoriter. Dengan kata lain, orangtua perlu menjadi pemimpin sekaligus sahabat, pemberi ketetapan sekaligus penerima masukan; yang dalam bahasa

${ }^{6}$ Sebagaimana dikutip oleh Thompson, Keluarga Sebagai Pusat Pembentukan, 55. ${ }^{7}$ Sebagaimana dikutip oleh Mary Go Setiawan, Menerobos Dunia Anak (Bandung: Kalam Hidup, 2004), 191. 
McGee, orang tua yang "menerima dan suportif."8 Dengan model kepemimpinan seperti ini maka rumah menjadi tempat kesukaan anak. Anak akan merasa dihargai, diterima dan didengarkan sehingga ia merasa aman dalam meyakini bahwa ia dibutuhkan dan didengarkan. Situasi yang demikian akan membentuk karakter dan harga diri anak pada keadaan yang ideal dan, pada gilirannya, akan membentuk iman dan persepsinya akan Tuhan.

\section{Menjadi Teladan}

Salah satu cara terbaik membentuk iman anak agar memiliki kehidupan yang takut akan Tuhan adalah dengan memberikan teladan kepada mereka. Tidak dapat dipungkiri, sarana pembelajaran paling efektif, terutama berkaitan dengan pembentukan karakter dan iman bukanlah melalui ruang kelas atau instruksi melainkan melalui teladan. Untuk menunjukkan kebenaran ungkapan tersebut, pernyataan Thompson berikut baik untuk diperhatikan:

Anak-anak belajar dari apa yang mereka jalani dalam kehidupan mereka. Mereka menyerap pengetahuan tentang dunia melalui kejadian-kejadian yang mereka alami dan amati. Kita tahu bahwa anak-anak lebih banyak belajar dari mengamati perilaku orang-orang dewasa daripada belajar dari perkataan atau nasihat. Mereka peka terhadap "kurikulum tersembunyi" di balik pengajaran--yang disampaikan lewat metode dan struktur yang bisa memperkuat atau justru bertentangan dengan isi pelajaran tersebut. ${ }^{9}$

\footnotetext{
${ }^{8}$ Robert S. McGee, Jim Craddock dan Pat Springle, The Parent Factor (Houston,
} TX: Rapha Publishing, 1989), 9.

9Thompson, Keluarga Sebagai Pusat Pembentukan, 13. 
Dengan kata lain, sekalipun perkataan mungkin membawa pengaruh signifikan dalam kehidupan anak, anak akan lebih terbentuk ketika mendapatkan teladan.

Berdasarkan fakta tersebut, orangtua harus selalu menyadari bahwa apa yang mereka lakukanlah yang paling diserap anak. Jika mereka menginginkan anak yang jujur, maka mereka harus memulainya terlebih dulu. Lagi, jika orangtua menginginkan anak yang rajin, maka orangtua haruslah didapati rajin dalam segala hal. Dan tentu saja hal yang sama juga berlaku bagi para orangtua yang menginginkan anak-anaknya takut akan Tuhan, orangtua harus terlebih dahulu menunjukkan teladan kehidupan bahwa mereka dalam segala perkara percaya dan taat kepada Tuhan dan firman-Nya. Dengan teladan tersebut, anak-anak tanpa harus diinstruksikan, pada umumnya akan terbentuk menjadi pribadi yang takut akan Tuhan.

Memberi Kasih yang Melimpah dan Disiplin yang Terarah

Anak perlu mendapatkan porsi kasih yang cukup dari orangtua agar bertumbuh menjadi pribadi yang mampu mengasihi dan menjalin hubungan yang sehat dengan Tuhan dan sesama. Sumbangsih dari pengalaman bertumbuh dalam kasih dengan kehidupan yang berbahagia sangatlah nyata. Sebagaimana dikutip oleh Simanjuntak, dalam penelitian yang dilakukan oleh Universitas Harvard, ditemukan hasil bahwa anakanak yang masa kecilnya penuh kasih sayang maka pada masa dewasanya hidupnya lebih kaya dengan hubungan dan sukacita, senang menjalin dan membangun hubungan denga orang lain 
dan hidup lebih lama. ${ }^{10}$ Hasil ini menunjukkan bahwa anak memang harus dididik dalam kasih sayang jika ingin melihat mereka bertumbuh menjadi pribadi yang sehat jasmani dan rohani. Atas fakta ini, tentunya adalah penting bagi para orangtua untuk memastikan bahwa anak-anak mereka mendapatkan kasih sayang yang melimpah dari orangtua dan keluarga mereka.

Namun, dalam mendidik anak, kasih sayang harus dibarengi dengan disiplin. Hal ini perlu ditegaskan mengingat banyaknya pengabaian terhadap faktor ini. Walaupun dalam konteks iman Kristen, di dalam kasih selalu terkandung makna adanya disiplin, namun tidak sedikit orangtua yang tidak melihat keduanya sebagai satu paket. Akibatnya bukannya kebaikan, melainkan kehancuran pada diri anak karena terlalu dimanja. Pernyataan Susabda tentang hal ini perlu dikutip:

Orangtua tidak dapat membedakan antara "senang anak" dan "sayang anak."....Setiap anak lahir dalam dosa, tanpa disiplin yang benar maka anak akan mengembangkan bakat-bakat dosanya. Senang anak tanpa sayang (love agaphe) pada anak justru merusak dan menghasilkan gap antara anak dengan orangtua, sesama bahkan Allah. Orangtua yang sayang anak akan tidak segan-segan memukulnya. ${ }^{11}$

Namun harus diingat, disiplin yang diberikan haruslah terarah dan terukur. Ini berarti orangtua melaksanakan disiplin karena sudah merancang, mempertimbangkan, menyepakati, dan untuk mencapai tujuan, yaitu pertumbuhan iman dan karakter. Disiplin tidak boleh diberikan sebagai pelampiasan nafsu, untuk kepetingan diri sendiri, atau sebagai ekspresi dari kebencian

\footnotetext{
10Julianto Simanjuntak, Membangun Kesehatan Mental Keluarga dan Masa Depan Anak (Jakarta: Gramedia Pustaka Utama, 2012), 233-235.

${ }^{11}$ Yakub B. Susabda, Pastoral Konseling, jil. 2 (Malang: Gandum Mas, 2003), 169.
} 
terhadap diri sendiri. ${ }^{12}$ Dengan pemberian disiplin yang demikian, anak diharapkan bertumbuh menjadi pribadi yang takut akan Tuhan.

\section{KESIMPULAN}

Membentuk generasi yang takut akan Tuhan adalah panggilan bagi setiap orangtua Kristen. Setiap orangtua Kristen bertanggungjawab secara khusus kepada Tuhan atas anak-anak mereka. Oleh karena itu adalah perlu bagi setiap orangtua Kristen untuk memperhatikan dan melaksanakan apa saja yang bisa membuat anak-anak mereka memiliki kehidupan yang takut akan Tuhan.

\section{DAFTAR PUSTAKA}

Dinkmeyer, Don dan Gary D. McKay. Raising a Responsible Child. New York: Fireside, 1996.

Douglas, J.D. "Takut." Dalam Ensiklopedi Alkitab Masa Kini. Jilid II. Jakarta: YKBK/OMF, 1995.

Longman III, Tremper. The Fear of The Lord is Wisdom. Grand Rapids, MI: Baker Academic, 2017.

McGee, Robert S., Jim Craddock dan Pat Springle. The Parent Factor. Houston, TX: Rapha Publishing, 1989.

Setiawan, Mary Go. Menerobos Dunia Anak. Bandung: Kalam Hidup, 2004.

Simanjuntak, Julianto. Membangun Kesehatan Mental Keluarga dan Masa Depan Anak. Jakarta: Gramedia Pustaka Utama, 2012. 
Susabda, Yakub B. Pastoral Konseling. Jilid 2. Malang: Gandum Mas, 2003.

Thompson, Marjorie L. Keluarga Sebagai Pusat Pembentukan. Jakarta: BPK Gunung Mulia, 2012.

Tripp, Tedd. Menggembalakan Anak Anda. Malang: Gandum Mas, 2002. 